\title{
Association Between Posture and Quality of Life: Implications for Children with Cancer
}

\author{
Jennifer Raybin ${ }^{1}$, Verna Hendricks-Ferguson ${ }^{2}$, and Teri Hernandez ${ }^{3}$ \\ ${ }^{1}$ Children's Hospital Colorado \\ ${ }^{2}$ Saint Louis University School of Nursing \\ ${ }^{3}$ University of Colorado - Anschutz Medical Campus
}

November 12, 2021

\begin{abstract}
Background: Children with cancer experience decreased quality of life. The National Institutes of Health has recommended examination of quality of life factors to promote development of clinical interventions to reduce suffering. Measuring quality of life in children based on self-report instruments is limited by subjectivity, age, and developmental stage. Assessment of posture is a pioneering objective physical measure that may augment quality of life preceptions among individuals with cancer. Procedure: This systematic literature review synthesized published evidence regarding the relationship between posture and quality of life. A systematic search using PRISMA guidelines identified articles describing studies of human subjects that included the variables of a) posture measured by the standard thoracic kyphosis angle; and b) quality of life or depression/mood. A total of 14 eligible studies met inclusion criteria (published 2000-2018). Studies were graded for level of evidence and themes were identified. Results: No studies were found in children with cancer. The majority of the studies ( 8 of 14) were rated at the moderate level. Key review findings include evidence supporting: 1) a consistent bidirectional relationship between posture and quality of life; 2) that when posture improves, quality of life also increases; and when depression decreases, posture improves; and 3) emotion is expressed through posture. Conclusion: If posture is a sensitive and precise measure of quality of life, it could strengthen existing measurements and give a more complete picture to in turn identify children who may benefit from supportive care interventions during cancer treatment.
\end{abstract}

\section{Association Between Posture and Quality of Life: Implications for Children with Cancer}

Jennifer L. Raybin, PhD, RN, CPNP ${ }^{1,2}$; Verna Hendricks-Ferguson, PhD, RN, FPCN, FAAN ${ }^{3}$; Teri L. Hernandez, $\mathrm{PhD}, \mathrm{RN}^{2}$

Affiliations: 1. Center for Cancer and Blood Disorders, Children's Hospital Colorado; 2. University of Colorado Anschutz Medical Campus College of Nursing and School of Medicine; 3. Saint Louis University School of Nursing

\section{Address all correspondence to:}

Jennifer L. Raybin, PhD, RN, CPNP

Children's Hospital Colorado

13123 E. $16^{\text {th }}$ Ave, B115

Aurora, CO 80045

Telephone: 720-777-3407

Fax: 720-777-7287 
E-mail: Jennifer.Raybin@childrenscolorado.org

Word count: Abstract 244, Text 3351

Number of Tables: 3

Number of Figures: 3

Running title: Association Between Posture and Quality of Life

Key Words: Posture; Thoracic Kyphosis; Quality of Life; Pediatric; Cancer

\title{
Abbreviations:
}

\begin{tabular}{ll}
\hline QOL & Quality of life \\
\hline PRISMA & Preferred Reporting Items for Systematic Reviews and Meta-analyses \\
RCT & Randomized controlled trial \\
HRQOL & Health related quality of life \\
ICC & Intraclass correlation coefficient \\
SRS & Scoliosis Research Society Questionnaire \\
MDD & Major depressive disorder \\
SD & Standard deviation \\
PedsQL & Pediatric Quality of Life Inventory \\
\hline
\end{tabular}

\begin{abstract}
Background: Children with cancer experience decreased quality of life. The National Institutes of Health has recommended examination of quality of life factors to promote development of clinical interventions to reduce suffering. Measuring quality of life in children based on self-report instruments is limited by subjectivity, age, and developmental stage. Assessment of posture is a pioneering objective physical measure that may augment quality of life preceptions among individuals with cancer.
\end{abstract}

Procedure: This systematic literature review synthesized published evidence regarding the relationship between posture and quality of life. A systematic search using PRISMA guidelines identified articles describing studies of human subjects that included the variables of a) posture measured by the standard thoracic kyphosis angle; and b) quality of life or depression/mood. A total of 14 eligible studies met inclusion criteria (published 2000-2018). Studies were graded for level of evidence and themes were identified.

Results: No studies were found in children with cancer. The majority of the studies ( 8 of 14) were rated at the moderate level. Key review findings include evidence supporting: 1) a consistent bidirectional relationship between posture and quality of life; 2) that when posture improves, quality of life also increases; and when depression decreases, posture improves; and 3) emotion is expressed through posture.

Conclusion: If posture is a sensitive and precise measure of quality of life, it could strengthen existing measurements and give a more complete picture to in turn identify children who may benefit from supportive care interventions during cancer treatment.

One critical aspect of care for children with cancer is assessment of symptoms and quality of life (QOL) related to both the disease and side effects of aggressive therapies. ${ }^{1-3}$ Historically, QOL research instruments have been based on self-report responses. An objective physical measure could reduce the time and possible distress associated with questionnaires, yet changes in conventional circulating (plasma) biomarkers are confounded by both cancer treatments and disease progression. Therefore, we proposed investigation of posture as a promising physical sign of QOL in children with cancer, measured as thoracic kyphosis. Posture has been studied as a neurologic outcome measure in survivors of childhood leukemia and brain tumors, ${ }^{4-6}$ but not as a QOL outcome for children in active treatment for cancer. This systematic review investigates 
the concept of physical posture as a supplemental measure of QOL that could be used by pediatric oncology practitioners.

Darwin theorized that humans and animals express emotions in their body positions (e.g., abnormal spinal curvatures). ${ }^{7}$ Assessing the presence of a Cobb angle on the spine is recognized as the gold-standard measurement of thoracic kyphosis. ${ }^{8}$ Thoracic kyphosis can also be measured with a manual inclinometer (Figure 1). ${ }^{9}$

Precedence for a physical sign to augment subjective reports exists with concepts such as a) step counts and walk tests for physical activity, b) restlessness for pain, and c) breathlessness, respiratory rate, or facial expression for dyspnea. For example, the ability to understand breathing distress through physical expressions at end of life when the person can no longer communicate has been studied and documented. ${ }^{10,11}$ Adding physical posture to QOL measures could give a more complete picture of a person's state in a similar manner. Before we proceed with more testing, a broad approach with a systematic review was thought to be warranted because causality or direction of the variables is not yet known (whether posture impacts QOL or vice versa).

Based on clinical observation by our dance/movement therapist of children receiving cancer treatment, we examined posture as an exploratory QOL outcome measure. Evaluation of the impact of a creative arts therapy intervention among 100 children with cancer showed evidence of cross-sectional and longitudinal relationships between posture and QOL questionnaire scores. At baseline, posture was moderately correlated with QOL $(\beta=0.33, \mathrm{p}<.05) .{ }^{12}$ Over time, posture and QOL improved along the same trajectory $(\mathrm{p}<$ .05 for time* group interaction). ${ }^{13}$ These statistically significant results led us to investigate the literature to theoretically support this finding.

Examination of the relationship between posture and QOL in children with cancer may provide a novel, objective, non-invasive, and inexpensive measure of QOL. With further study, posture could be shown to be a useful measure as a predictive physical sign of QOL, or perhaps for surveillance of QOL during cancer treatments. ${ }^{14}$ Establishing proof of concept in adults or other populations is often required prior to exploration in a high risk pediatric population such as children with cancer. Therefore, the purpose of this systematic review is to provide an evaluation of existing evidence regarding the relationship between posture and QOL published in the medical literature in all populations to lay the foundation to support investigation of this relationship among children with cancer.

\section{Methods}

\section{Conceptual Framework}

The Shape-Shifter Model is a biobehavioral approach to guide the biopsychosocial research of symptoms. ${ }^{15}$ Based on this model, independent and dependent variables (determinants and phenomena, respectively) can change positions in an association, creating bi-directionality and potentially increased explanatory power in the study of associations between biologic or psychologic/behavioral factors and a symptom. ${ }^{15}$ The variables of study in this review are posture, depression/mood, and QOL.

\section{Data Extraction, Quality Assessment, Search Methods}

The review team included a doctoral student and two senior professors with consulting by an experienced medical librarian. Variables for QOL and depression/mood were measured by established instruments. Posture was measured by inclinometer, x-ray, chest height, or perceived body postures. As informed by the Shape-Shifter Model, ${ }^{15}$ two levels of search strategy (biologic, behavioral) were employed, guided by the Preferred Reporting Items for Systematic Reviews and Meta-analyses (PRISMA) statement. ${ }^{16}$ Inclusion criteria were: a) posture measured by the standard thoracic kyphosis angle; b) measurement of QOL or depression/mood; c) English language; d) fully published empirical studies with descriptive, cross-sectional, and randomized clinical trial (RCT) designs. Exclusion criteria were: a) surgical posture intervention studies, abstracts, case studies, case reports, dissertations, literature reviews, and qualitative studies. No studies were identified in children with cancer (Figure 2). 
First, the existing literature reporting an association between posture and QOL (Biologic Perspective) was searched using PubMed and Ovid Medline with the indexed term for QOL, and the key words postureand thoracic kyphosis (MeSH headings Quality of Life or Life Quality or Health Related Quality of Life or HRQOL ). The initial search included the prior ten years from 2008 to 2018 , but due to a low number of results, the time range was increased to the years from 2000 to 2018. The resulting 118 articles were scanned for appropriate titles and abstracts, revealing 8 studies (Table 1). Next, existing research literature investigating the relationship between mood (defined as emotional reactions or depression) and posture (Behavioral Perspective) was searched using Pubmed and Ovid Medline for the prior ten years from 2008 to 2018 using the key wordsposture, thoracic kyphosis, mood, depression, and anxiety . This resulted in 307 articles. Resulting articles were scanned for appropriate titles and abstracts, revealing 6 studies (Table 2). In summary, 14 total studies met criteria for inclusion in this systematic review.

\section{Evidence Rating}

The team then used the Grading of Recommendations Assessment, Development, and Evaluation (GRADE) tool to rate strengths and limitations. Evidence quality with GRADE is evaluated by examining methodological flaws, consistency, directness, and effect size. ${ }^{17,18}$ This tool has been successfully used in other reviews of studies in the field of pediatric oncology ${ }^{19,20}$ and includes four evaluation ratings (high, moderate, low and very low) (Table 3). One team member initially evaluated and rated each of the 14 selected records. Matrix tables including GRADE scores were developed and discussed during scheduled on-line conference calls with all research team members. All team members evaluated each article and the GRADE rating level of evidence for each article was discussed until $100 \%$ consensus was reached. ${ }^{17}$

\section{Results}

\section{Level of Evidence}

Four studies were rated with evidence levels of low; ${ }^{8,21-23}$ seven studies with moderate, ${ }^{24-30}$ and three studies with high (Tables 1,2). ${ }^{31-33}$ In terms of lack of methodologyrigor, institutional review board approval was not reported in three of the studies. ${ }^{21,26,29}$ Power calculations for sample size were not reported in 10 of the studies..$^{8,21-26,28-30}$ Randomization procedures were not used in 12 studies. $^{8,21-30,32}$ Six studies had sample sizes of less than 50 participants. ${ }^{8,22,23,27-30}$ Two studies were limited by selection bias (convenience sampling), ${ }^{21,31}$ and two studies used outcome measures without discussion of validity. ${ }^{26,29}$ Consistency was evident in seven studies where reproducibility of measures and interventions was reported. ${ }^{8,22,25,27,31-33} D i$ rectness prompts for an evaluation of similarities between comparison groups and was discussed in comparison studies of different types of kyphosis ${ }^{21,22,24,25}$ and in one study in which there was an unequal population comparison due to a predominance of females. ${ }^{28}$ Effect size was most certain in the three studies that rated as high level of evidence due to power analysis, adequate sample size, narrow confidence intervals, or large effect size. ${ }^{31-33}$ Importantly, all 3 studies with a high level of evidence were identified in the Biologic Perspective search (Table 1).

\section{Results from the Biologic Perspective}

A total of eight studies were reviewed related to biologic criteria (i.e., posture as independent variable, and QOL as dependent variable; Table 1). Five of these studies included adults aged older than 50 years ${ }^{31-33}$ and diagnosed with osteoporosis. ${ }^{22,25}$ Three of these studies included children/adolescents (aged 8 to 21 years) diagnosed with scoliosis. ${ }^{8,21,24}$ Two of the eight studies included a RCT with randomization of subjects to either an exercise intervention and/or a control group. ${ }^{31,33}$ One of the eight studies used a quasi-experimental study design with investigator assignment of subjects to either a spinal exercise versus a control exercise. ${ }^{8}$ Two of the eight studies used a cross-sectional comparative study design to examine the relationship of posture measurements and QOL. ${ }^{22,25}$ Three of the eight studies used a comparative retrospective chart review design involving a review of indicators of posture and QOL among subjects ${ }^{8,21,24}$. A total of 821 participants were mostly female, and aged from 4 to 90 years. Five of the eight studies included relatively large sample sizes (> 50 participants)..$^{21,24,25,31,32}$ Three of the eight studies reported performing an apriori power analysis. ${ }^{31-33}$ Six of the eight studies provided evidence of a statistically significant association between 
posture and QOL.

Kyphosis is Related to QOL across Underlying Diagnoses

Evidence from two cross-sectional studies of osteoporosis supported a statistically significant moderate effect size between kyphosis and QOL. ${ }^{22,25}$ In a non-randomized double-blind, placebo-controlled repeated measures intervention study, Jang, Hughes, Oh, Kim ${ }^{32}$ focused on evaluating a corrective exercise intervention. The results showed significant improvement in the participants' kyphosis angle and QOL in the intervention group only. The QOL measures for these studies were the Rand 36 and the SF 36, both of which were reported to have adequate validity and reliability.

Two comparative studies focused on the evaluation of scoliosis in adolescents provided evidence that suggested small to moderate inverse associations between kyphosis QOL: $\mathrm{r}=-0.246^{24}$ and $\mathrm{r}=-0.601 .{ }^{21}$ Investigators in the first of these studies compared adolescents' spine measurements according to three groups (severe kyphosis, idiopathic scoliosis, normal controls) and their results showed the poorest level of QOL in the adolescent group with severe scoliosis and the highest level of QOL in the control group of adolescents, suggesting a dose-response association. ${ }^{24}$ The QOL measure for the studies of scoliosis were varying iterations of the validated scoliosis outcome measure (SRS) which has also shown adequate reliability.

In another study, the investigators ${ }^{8}$ conducted a retrospective comparative analysis study design that provided evidence of superior improvement in posture angle resulting from a spinal exercise corrective intervention that was accompanied by improved QOL in adolescents with scoliosis. However, these differences were not shown in the conventional exercise-control condition. Despite the differing etiologies of kyphosis, there was a consistent negative association between posture/kyphosis and QOL in these two diverse populations.

Kyphosis is Modifiable

Evidence from four studies demonstrated that kyphosis may improve after receiving an exercise intervention. Less consistent evidence suggested a parallel improvement in QOL with the improvement of kyphosis. In two clinical trials of older adults with osteoporosis, an exercise intervention improved kyphosis but showed no impact on the adults' QOL. ${ }^{31,33}$ In two RCT designed studies that evaluated an exercise intervention among adolescents $^{8}$ and older adults, ${ }^{32}$ the results showed an improvement in the kyphosis angle and QOL measures among participants receiving the intervention compared to no changes among the control group. Although it has been well documented that exercise improves QOL, our results suggest that the improvement in QOL may not be limited to the exercise itself, but also the improvement in posture. For example, the double-blind controlled (but not randomized) study of Jang, Hughes, Oh, Kim ${ }^{32}$ showed a time*group interaction that supported an association between kyphosis and QOL in spite of exercise in both groups. Moreover, in the study by Noh et al., ${ }^{8}$ improved QOL was not demonstrated in the control group exercise condition. Thus, kyphosis may be modifiable following an intervention and may be a sensitive indicator of QOL.

Differing Posture Measurements

Measurement precision is critical to the study of posture as an objective physical marker. Many studies used radiographic analysis (the gold standard Cobb angle) to measure the angle of kyphosis compared to QOL. ${ }^{8,21,24,25,33}$ Inclinometers were employed in 2 studies in this review to evaluate posture after an exercise intervention and found statistically significant improvement in kyphosis over time. ${ }^{31,32}$ In one study using a cross-sectional design, a statistically significant relationship between posture (based on inclinometer measurements) and QOL was shown in 34 adult women with osteoporosis $(\mathrm{r}=-0.48, \mathrm{p}<0.005) .{ }^{22}$ The inclinometer had reported adequate measurement precision with high interrater reliability (intraclass correlation coefficients [ICCs] ranging from 0.89 to 0.96$).{ }^{31,32,34}$

\section{Results from the Behavioral Perspective}

Investigators examined potential relationships in: (a) depression and posture in three studies ${ }^{23,27,28}$ and (b) mood and emotions and posture in three studies. ${ }^{26,29,30}$ Study designs included (a) case-control; ${ }^{28}$ (b) control group condition; ${ }^{29,30}$ (c) cross-sectional; ${ }^{23,27,29}$ and (d) repeated-measures. ${ }^{26,28,30}$ There were a total 
of 345 participants across all six studies and most were women, with one including children. ${ }^{30}$ In all of the six reviewed studies, a relationship between mood and posture was reported. Five studies provided a moderate level of evidence and one provided a low level of evidence (Table 2). The measures used to evaluate body posture were consistent, such as using a digital camera system to measure upper body height. ${ }^{23,26-28,30}$

Depression Is Linked to Poor Posture

In one study ${ }^{28}$ the investigators found a significant presence of kyphosis during a depressive episode (vs. control) (mean $140^{\circ}$, SD $5^{\circ}$ and mean $145^{\circ}$, SD $5^{\circ}$; p<.001) among 34 adults diagnosed with a major depressive disorder. After this group of adults received 8-10 weeks of treatment, the investigators reported an improvement of $\sim 5^{\circ}$ in the kyphosis angle was observed in parallel with reduced self-reported depression. In a second study, ${ }^{27}$ investigators evaluated spine measurements among 72 female adults with recurrent major depressive disorder (MDD), and found worse posture measurements (angle measured measured by digital camera) compared to those with a single episode $\left(139.38^{\circ}, \mathrm{SD}=1.19\right.$ and $\left.147.13^{\circ}, \mathrm{SD}=1.35 ; \mathrm{p}<0.001\right)$. In a third study with 12 adults, ${ }^{23}$ the investigators' results provided evidence of: a) medium and large correlations between depression and kyphotic posture $(\mathrm{r}=0.36-0.51 ; \mathrm{p}=0.01-0.05)$ and $\mathrm{b})$ a significant correlation between "usual depression" (defined as a chronic feeling and measured by an analogue scale) and shoulder inclination $(\mathrm{r}=0.822 ; \mathrm{p}=0.02)$.

Emotion May Be Revealed by Posture

Overall mood and emotional state were also associated with posture. Three studies used innovative methods to measure the connection between emotions and body stature. Investigators found a positive association between positive emotion and chest height in young children $(\mathrm{r}=0.37, \mathrm{p}=0.03) .{ }^{30}$ Negative emotions were related to a reduced height posture by introducing an emotional concept (disappointment) and measuring chest height $(\mathrm{t}(56)=0.2 .76, \mathrm{p}<0.004) .{ }^{26}$ Observers rated emotions more accurately when looking at body posture in addition to facial expression compared to using facial expressions only $(\mathrm{F}(1,14)=96.9, \mathrm{p}<0.001)$, suggesting that it was the interaction of body posture with facial expression that resulted in an improved prediction of an emotion. ${ }^{29}$

\section{Discussion}

\section{Shape Shifting Lens}

The existing evidence suggests that a shape-shifting bi-directional association exits between posture and QOL in youth with scoliosis (aged 8 to 21 years) and adults with osteoporosis (over age 50 years). ${ }^{15}$ If this remains true in children with cancer, a child's QOL could be evaluated with a simple, non-invasive clinical measurement tool. The inclinometer may avoid otherwise unnecessary spinal radiographs, and may be more feasible to collect in children with cancer evidenced by the completion rate in our study for the inclinometer measure $(68 \%)$ was higher than the child report on the PedsQL questionnaire $(60 \%) .{ }^{12}$

While four studies demonstrated consistently that kyphosis is modifiable with exercise, ${ }^{8,31-33}$ two of the studies supported that the improvement in kyphosis was in fact accompanied by improved QOL, $, 8,32$ a finding not explained by the known improvement in QOL with exercise. Perhaps this concept could be generalized to children with temporary kyphosis due to the effects of cancer and its treatment, whereby measurement of kyphosis over time could be a simpler measure of QOL to more easily tailor supportive care. Furthermore, the scoliosis studies showed that measurement of kyphosis is feasible in the pediatric population, and perhaps the more malleable spines in children without orthopedic disorders could show improvement in kyphosis with improved QOL with cancer treatment. This concept was supported by a recent RCT in children with cystic fibrosis. Although the investigators did not include QOL as an outcome, rendering it ineligible for inclusion here, they demonstrated improved posture with a physical exercise intervention. ${ }^{35}$ If kyphosis is modifiable, even in elderly adults and patients with orthopedic disorders, and tracks with QOL, it could be an appropriate surrogate measure showing the impact of QOL interventions.

In shape-shifting contrast, the behavioral studies consistently demonstrated an inverse association between QOL (as depression or mood) and posture. Three of the studies used behavioral techniques to evoke posi- 
tive and negative emotions to demonstrate the association. ${ }^{26,29,30}$ Additionally, these three studies further supported that by measuring thoracic kyphosis, the assessment of a child's mood (as an aspect of QOL) could be measured with an inclinometer. ${ }^{36}$ Similarly, we found correlation between mood measured by the Faces scale and the posture measure in our study in children with cancer $(\beta=0.26) .{ }^{12}$ The finding of a statistically significant correlation with a strong effect size between depression and shoulder inclination may also be highly clinically useful. ${ }^{23}$ If mood is related to posture in older women with osteoporosis, perhaps this finding can be replicated in children with cancer. Indeed, our prospective study did confirm this concept without a significant difference between males and females, specifically in children with cancer. ${ }^{12}$

The bi-directional relationship between QOL and posture are bi-directionally could be explained physiologically by established connections between the limbic system, shown to govern emotional response, and the postural response seen in major depression. This was recently supported in a study of electroconvulsive therapy for depression and the effects on the neuroplasticity of the limbic system in the brain where brain volumes increased significantly related to symptom improvement $(\mathrm{p}<.01) .{ }^{37}$ Similarly, the field of rehabilitation medicine has used the Bobath practice model based in neuroscience to integrate posture by evaluating critical client cues such as postural alignment on the outcomes of pain and function (but not QOL) in the recovery from stroke and spinal cord injury. ${ }^{38}$

\section{Origins with Darwin}

Our findings support Darwin's original concept that QOL is often expressed by physical body positions (e.g., spine curvatures) with an overall moderate level of evidence. Further study using rigorous methods could validate this correlation, specifically in children with cancer. Not only should the measures of QOL and posture be explored together in this population, but future studies could examine relevant covariates depicted in Figure 3, such as sex differences, changes over time, disease status, treatment effects, and the relationship of the central venous catheter to QOL. Related to Darwin's study of biologic evolution, the factors of sex and age differences in the relationship of posture and emotion may also prove to be important clinical assessments by clinicians. Interestingly, in our study of 100 children with cancer, although we did not find a significant difference in posture by sex, we did find that older age was correlated with worse posture $(\beta=0.41){ }^{12}$

\section{Limitations}

Only three of the reviewed studies were rated with a high level of evidence based on rigorous experimental prospective RCT designs that included power analysis. Although kyphosis and QOL may track along the same direction (correlation), a causal inference cannot be made without a true experimental controlled study. The reviewed studies did not include equal representation of the sex demographic variable (i.e., recruited participants were primarily female) or pediatric oncology patients. Perhaps the underlying pathophysiology of osteoporosis or scoliosis affected the kyphosis in a different way than cancer would. Furthermore, characteristics of the study populations including previous life experiences were not well defined, which could impact their baseline QOL and/or posture status. Inconsistency in utilized posture and QOL measures make the findings less generalizable. Finally, we did not find evidence that posture is a more sensitive and precise measure of QOL than existing self-report or proxy-report questionnaires, so it fits better as a physical sign to augment QOL measurement than a surrogate biomarker. ${ }^{14}$

\section{Conclusions}

Supportive care for children with cancer may be augmented by our findings, but further exploration of relationships between posture and QOL in a large $\mathrm{RCT}$ is warranted. Although many questions remain about posture as a potential physical sign of QOL in children, evidence supports the suggestion traced back to Darwin that this biobehavioral pathway may provide a novel method to measure QOL in pediatric oncology. An accurate objective measure of QOL could provide an efficient tool to augment the outcome measurements of interventions to reduce distress in children receiving treatment for cancer.

Figure Legend: 
FIGURE 1 Application of manual inclinometers for thoracic kyphosis measurement (photo used with written permission from author who obtained informed consent). ${ }^{39}$

FIGURE 2 Preferred Reporting Items for Systematic Reviews and Meta-analyses (PRISMA) flow diagram of the systematic review article-screening procedure ${ }^{16}$

FIGURE 3 The posture angle, mood, depression, and quality of life are inter-related in a bidirectional manner and affected by cofounders and covariates. Adapted from Corwin. ${ }^{15}$

Disclosure: The authors have no conflicts of interest to disclose.

Acknowledgement: The authors would like to acknowledge Marilyn Krajicek, EdD, RN, FAAN for her guidance and wisdom in the program of research. We would also like to thank Patricia Mowry, MS, BCDMT, CMA, LPC, dance/movement therapist, for the concept development in her work with children with cancer.

Disclaimer: This work was supported by the American Cancer Society 133523-DSCN-19-050-01-SCN.

TABLE 1 Posture as Independent Variable, Quality of Life (QOL) as Dependent Variable

\begin{tabular}{|c|c|c|c|c|c|}
\hline $\begin{array}{l}\text { Source and } \\
\text { GRADE } \\
\text { Evidence Level }\end{array}$ & Purpose & $\begin{array}{l}\text { Design and } \\
\text { Sample }\end{array}$ & $\begin{array}{l}\text { Independent } \\
\text { Variable or } \\
\text { Intervention }\end{array}$ & $\begin{array}{l}\text { Dependent } \\
\text { Variable }\end{array}$ & Findings \\
\hline $\begin{array}{l}\text { Petcharaporn, } \\
\text { Pawelek, } \\
\text { Bastrom, } \\
\text { Lonner, Newton } \\
21 \text { GRADE } \\
\text { Level: Low }\end{array}$ & $\begin{array}{l}\text { To evaluate the } \\
\text { association } \\
\text { between thoracic } \\
\text { hyperkyphosis } \\
\text { and patient QOL } \\
\text { measures. }\end{array}$ & $\begin{array}{l}\text { Retrospective } \\
\text { comparative } \\
\text { study } 50 \text { children } \\
\text { with scoliosis, } \\
\text { thoracic } \\
\text { kyphosis }>45^{\circ} \\
\text { and } 50 \text { children } \\
\text { without scoliosis; } \\
\text { ages } 14+4 \\
(8-18) \text { years, } \\
50 \% \text { female }\end{array}$ & Posture (X-ray) & QOL (SRS-24) & $\begin{array}{l}\text { Significant } \\
\text { negative } \\
\text { correlation } \\
\text { between } \\
\text { kyphotic curve } \\
\text { and all domains } \\
\text { of QOL scores } \\
(\mathrm{r}=-0.601 \text {, } \\
\mathrm{p}<0.001) \text {. } \\
\text { Self-image } \\
\text { showed the } \\
\text { strongest } \\
\text { association } \\
(\mathrm{r}=-0.66, \\
\mathrm{p}<0.001) .\end{array}$ \\
\hline
\end{tabular}




\begin{tabular}{|c|c|c|c|c|c|}
\hline $\begin{array}{l}\text { Source and } \\
\text { GRADE } \\
\text { Evidence Level }\end{array}$ & Purpose & $\begin{array}{l}\text { Design and } \\
\text { Sample }\end{array}$ & $\begin{array}{l}\text { Independent } \\
\text { Variable or } \\
\text { Intervention }\end{array}$ & $\begin{array}{l}\text { Dependent } \\
\text { Variable }\end{array}$ & Findings \\
\hline $\begin{array}{l}\text { Greendale, } \\
\text { Huang, } \\
\text { Karlamangla, } \\
\text { Seeger, Crawford } \\
{ }^{1} \text { GRADE } \\
\text { Level: High }\end{array}$ & $\begin{array}{l}\text { To assess } \\
\text { whether a } \\
\text { specific yoga } \\
\text { intervention can } \\
\text { reduce } \\
\text { hyperkyphosis. }\end{array}$ & $\begin{array}{l}\text { RCT } 118 \text { people, } \\
\text { ages } 75.5 \text { years } \\
\text { (range } 59.8-90 \text { ), } \\
81 \% \text { women, } \\
88 \% \text { caucasian }\end{array}$ & $\begin{array}{l}\text { Intervention: } \\
\text { yoga class } \\
\text { 1-hour, } 3 \\
\text { days/week for } 6 \\
\text { months } \\
\text { Attention } \\
\text { Control: } \\
\text { monthly } \\
\text { luncheon and } \\
\text { seminar and } \\
\text { mailings }\end{array}$ & $\begin{array}{l}\text { Posture } \\
\text { (Debrunner } \\
\text { kyphometer), } \\
\text { QOL (Rand } \\
\text { 36-item) }\end{array}$ & $\begin{array}{l}\text { Yoga group had } \\
0.93^{\circ} \text { decrease } \\
\text { (improvement) } \\
\text { in kyphosis angle } \\
\text { while those in } \\
\text { control had an } \\
\text { increase of } 0.82^{\circ} \\
(4.4 \% \text { difference) } \\
(\mathrm{p}=.005) \text { Yoga } \\
\text { group had } \\
\text { decrease } \\
\text { (improvement) } \\
\text { in kyphosis index } \\
\text { of } 0.006 \text { while } \\
\text { those in control } \\
\text { had an increase } \\
\text { (worsened) of } \\
0.003 \text { (5\% } \\
\text { difference)(p = } \\
.004) . \\
\text { Intervention did } \\
\text { not result in } \\
\text { significant } \\
\text { difference in } \\
\text { QOL between } \\
\text { groups. }\end{array}$ \\
\hline $\begin{array}{l}\text { Lonner, Yoo, } \\
\text { Terran, } \\
\text { Sponseller, } \\
\text { Samdani, Betz, } \\
\text { Shuffelbarger, } \\
\text { Shah, Newton }{ }^{24} \\
\text { GRADE } \\
\text { Level: } \\
\text { Moderate }\end{array}$ & $\begin{array}{l}\text { To compare } \\
\text { QOL and } \\
\text { kyphosis in } 3 \\
\text { groups } \\
\text { (Scheuermann } \\
\text { kyphosis (SK), } \\
\text { adolescent } \\
\text { idiopathic } \\
\text { scoliosis (AIS), } \\
\text { normal } \\
\text { population). }\end{array}$ & $\begin{array}{l}\text { Prospective } \\
\text { comparative } \\
\text { study } 86 \text { patients } \\
\text { with SK ( } 40 \% \\
\text { female, mean age } \\
16.1 \text { years ( } 4-22 \\
\text { years)) } 184 \\
\text { patients with } \\
\text { AIS }(78 \% \\
\text { female, mean age } \\
14.9(10-21)) 31 \\
\text { normal controls } \\
(72 \% \text { female, } \\
\text { mean age } 14.2 \\
(11-17))\end{array}$ & Posture (xray) & $\begin{array}{l}\text { QOL (Visual } \\
\text { Analog Scale } \\
\text { and SRS-22) }\end{array}$ & $\begin{array}{l}\text { Patients with SK } \\
\text { had significantly } \\
\text { lower scores on } \\
\text { SRS-22 (mean } \\
3.61, \text { SE 0.05) } \\
\text { than patients } \\
\text { with AIS (mean } \\
3.94, \text { SE 0.02), } \\
\text { or the control } \\
\text { (mean 4.31, SE } \\
0.08, \mathrm{p}<0.001) \text {. } \\
\text { Negative } \\
\text { correlation } \\
\text { between } \\
\text { kyphosis and } \\
\text { SRS-22 scores in } \\
\text { the male subset } \\
(\mathrm{r}=-0.246 \text {, } \\
\mathrm{p}=0.001) \text {. }\end{array}$ \\
\hline
\end{tabular}




\begin{tabular}{|c|c|c|c|c|c|}
\hline $\begin{array}{l}\text { Source and } \\
\text { GRADE } \\
\text { Evidence Level }\end{array}$ & Purpose & $\begin{array}{l}\text { Design and } \\
\text { Sample }\end{array}$ & $\begin{array}{l}\text { Independent } \\
\text { Variable or } \\
\text { Intervention }\end{array}$ & $\begin{array}{l}\text { Dependent } \\
\text { Variable }\end{array}$ & Findings \\
\hline $\begin{array}{l}\text { Noh, You, Koh, } \\
\text { Kim, Kim, Ko, } \\
\text { Shin }{ }^{8} \text { GRADE } \\
\text { Level: Low }\end{array}$ & $\begin{array}{l}\text { To compare } \\
\text { therapeutic } \\
\text { effects of a } \\
\text { corrective spinal } \\
\text { exercise } \\
\text { technique (CST) } \\
\text { and a } \\
\text { conventional } \\
\text { exercise (CE) } \\
\text { program on } \\
\text { altered spine } \\
\text { curvature and } \\
\text { QOL in patients } \\
\text { with AIS. }\end{array}$ & $\begin{array}{l}\text { Retrospective } \\
\text { comparative } \\
\text { study } 32 \\
\text { patients with } \\
\text { AIS, CST }(13.8 \\
+2.8 \text { years, } 75 \% \\
\text { female) versus } \\
\text { CE }(14.9+2.3 \\
\text { years, } 88 \% \\
\text { female) }\end{array}$ & $\begin{array}{l}\text { Intervention: } \\
\text { CST Control: } \\
\text { CE Each group: } \\
60 \text { min/day, 2-3 } \\
\text { times/wk. Mean } \\
30 \text { sessions. }\end{array}$ & $\begin{array}{l}\text { Posture } \\
\text { (X-ray), QOL } \\
\text { (SRS-22) }\end{array}$ & $\begin{array}{l}\text { Greater } \\
\text { improvement in } \\
\text { posture angle in } \\
\text { CST }\left(8.1^{\circ}+4.5\right. \\
\text { [SD] in CST) } \\
\text { compared to CE } \\
\left(4.3^{\circ}+2.1 \text { in }\right. \\
\text { CE, } 95 \% \text { CI - } 6.4 \\
\text { to }-1.2, \\
\mathrm{p}=0.003) \text {. The } \\
\text { intervention } \\
\text { group had } \\
\text { improved } \\
\text { pre-post QOL } \\
\text { (pre: } 3.8+-1.8 \\
\text { vs. post: } \\
4.5+-0.4, \\
\text { p=0.012) while } \\
\text { the control } \\
\text { group did not. }\end{array}$ \\
\hline $\begin{array}{l}\text { Sangtarash, } \\
\text { Manshadi, } \\
\text { Sadeghi } 22 \\
\text { GRADE } \\
\text { Level: Low }\end{array}$ & $\begin{array}{l}\text { To investigate } \\
\text { the relationship } \\
\text { between } \\
\text { magnitude of } \\
\text { kyphosis and } \\
\text { quality of life } \\
\text { (QOL) and gait } \\
\text { performance. }\end{array}$ & $\begin{array}{l}\text { Descriptive } \\
\text { cross-sectional } \\
\text { study } 34 \text { women } \\
\text { with } \\
\text { osteoporosis, } \\
\text { ages 50-68 years } \\
(60.8 \pm 4.40) .\end{array}$ & $\begin{array}{l}\text { Posture (dual } \\
\text { digital } \\
\text { inclinometer) }\end{array}$ & QOL (SF36) & $\begin{array}{l}\text { Significant } \\
\text { negative } \\
\text { correlation } \\
\text { between } \\
\text { kyphosis and } \\
\text { QOL }(r=-0.48, \\
\text { p }<0.005) .\end{array}$ \\
\hline $\begin{array}{l}\text { Jang, Hughes, } \\
\text { Oh, Kim } 32 \\
\text { GRADE } \\
\text { Level: High }\end{array}$ & $\begin{array}{l}\text { To identify } \\
\text { effects of } \\
\text { corrective } \\
\text { exercise for } \\
\text { thoracic } \\
\text { kyphosis on } \\
\text { posture, balance, } \\
\text { and well-being in } \\
\text { Korean older } \\
\text { women. }\end{array}$ & $\begin{array}{l}\text { Double-blind, } \\
\text { controlled, } \\
\text { repeated } \\
\text { measures } \\
\text { intervention } \\
\text { study } \\
\text { Convenience } \\
\text { assignment, } 50 \\
\text { women, ages } \\
74.6+4.6 \\
\text { (experimental } \\
\text { group) and } 76.4 \\
+4.9 \text { (control } \\
\text { group) }\end{array}$ & $\begin{array}{l}\text { Intervention: } \\
\text { thoracic } \\
\text { corrective } \\
\text { program, 1-hour, } \\
\text { twice weekly for } \\
8 \text { weeks Control: } \\
\text { education on } \\
\text { exercise and } \\
\text { booklet }\end{array}$ & $\begin{array}{l}\text { Posture (dual } \\
\text { digital } \\
\text { inclinometer, } \\
\text { Flexicurve), } \\
\text { well-being } \\
\text { (Geriatric } \\
\text { Depression Scale } \\
\text { Short Form, } \\
\text { SF-36) }\end{array}$ & $\begin{array}{l}\text { Intervention } \\
\text { group showed } \\
\text { significant } \\
\text { improvements in } \\
\text { percent change } \\
\text { of kyphosis angle } \\
\text { over time } \\
(-3.8 \pm 2.2 \%) \text { vs. } \\
\text { control } \\
(+1.4 \pm 3.8 \%) \text { (p } \\
<.01) \text {. Time by } \\
\text { group interaction } \\
\text { showed } \\
\text { significantly } \\
\text { better QOL on } \\
\text { both measures } \\
\text { for the } \\
\text { intervention } \\
\text { group } \\
(\text { p }<0.01-0.05) \text {. }\end{array}$ \\
\hline
\end{tabular}




\begin{tabular}{|c|c|c|c|c|c|}
\hline $\begin{array}{l}\text { Source and } \\
\text { GRADE } \\
\text { Evidence Level }\end{array}$ & Purpose & $\begin{array}{l}\text { Design and } \\
\text { Sample }\end{array}$ & $\begin{array}{l}\text { Independent } \\
\text { Variable or } \\
\text { Intervention }\end{array}$ & $\begin{array}{l}\text { Dependent } \\
\text { Variable }\end{array}$ & Findings \\
\hline $\begin{array}{l}\text { Katzman, } \\
\text { Parimi, Gladin, } \\
\text { Poltavskiy, } \\
\text { Schafer, Long, } \\
\text { Fan, Wong, Lane } \\
33 \text { GRADE } \\
\text { Level: High }\end{array}$ & $\begin{array}{l}\text { To determine if } \\
\text { specific exercise } \\
\text { improves } \\
\text { kyphosis, if it } \\
\text { differs between } \\
\text { men and women, } \\
\text { and if physical } \\
\text { function and } \\
\text { QOL are } \\
\text { affected. }\end{array}$ & $\begin{array}{l}\text { RCT } 60 \text { women, } \\
41 \text { men, } 70.0 \\
\text { years }(\mathrm{SD}=5.7)\end{array}$ & $\begin{array}{l}\text { Intervention: } \\
\text { kyphosis exercise } \\
\text { program, } 1 \text { hour } \\
\text { twice weekly for } \\
3 \text { months } \\
\text { Control: waitlist } \\
\text { for } 3 \text { months }\end{array}$ & $\begin{array}{l}\text { Posture (xray), } \\
\text { QOL (SRS-30, } \\
\text { Global health } \\
\text { index) }\end{array}$ & $\begin{array}{l}\text { Kyphosis angle } \\
\text { degree improved } \\
\text { more in the } \\
\text { intervention } \\
\text { group }\left(-3.8^{\circ},\right. \\
95 \% \text { CI }-5.3 \text { to } \\
-2.3) \text { than the } \\
\text { control }\left(+1^{\circ} \text {, }\right. \\
95 \% \mathrm{CI}-0.05 \text { to } \\
2.4 ; \mathrm{p}<0.0001) \text {. } \\
\text { Between group } \\
\text { changes in QOL } \\
\text { scores were not } \\
\text { significantly } \\
\text { different, } \\
\text { although both } \\
\text { groups had high } \\
\text { QOL at baseline. }\end{array}$ \\
\hline $\begin{array}{l}\text { Miyakoshi, } \\
\text { Kudo, Hongo, } \\
\text { Kasukawa, } \\
\text { Ishikawa, } \\
\text { Shimada } 25 \\
\text { GRADE } \\
\text { Level: } \\
\text { Moderate }\end{array}$ & $\begin{array}{l}\text { To compare } \\
\text { spinal alignment, } \\
\text { muscular } \\
\text { strength, and } \\
\text { QOL between } \\
\text { women with } \\
\text { post-menopausal } \\
\text { osteoporosis and } \\
\text { healthy } \\
\text { volunteers. }\end{array}$ & $\begin{array}{l}\text { Cross-sectional } \\
\text { comparative } \\
\text { study } 236 \\
\text { women patients } \\
\text { (ages } 69-75 \text { years } \\
\text { (SD } 6 \text { )) at } \\
\text { osteoporosis } \\
\text { clinic to } 93 \\
\text { healthy } \\
\text { volunteers }\end{array}$ & $\begin{array}{l}\text { Posture (X-ray, } \\
\text { SpinalMouse } \\
\text { surface } \\
\text { curvature) }\end{array}$ & QOL (SF-36) & $\begin{array}{l}\text { Women with } \\
\text { osteoporosis } \\
\text { were younger } \\
\text { but had worse } \\
\text { QOL scores } \\
\text { across SF-36 } \\
\text { scales compared } \\
\text { to controls (all } \\
\text { p }<0.05 ; \\
\text { difference } \\
\text { remained when } \\
\text { adjusted for age) } \\
\text { Physical scale } \\
\text { QOL } \\
\text { significantly } \\
\text { lower in the } \\
\text { osteoporosis } \\
\text { group (39.4, } 95 \% \\
\text { CI } 37.0 \text { to } 41.9 \\
\text { and } 47.5,95 \% \text { CI } \\
44.7 \text { to } 50.2, \mathrm{p}< \\
0.001) ; \text { Kyphosis } \\
\text { was correlated } \\
\text { with physical } \\
\text { QOL (r=0.253, } \\
\text { p }<0.05) .\end{array}$ \\
\hline
\end{tabular}

Legend: $\mathrm{QOL}=$ Quality of Life; RCT=Randomized Controlled Trial; SD=Standard Deviation; SRS=Scoliosis Research Society outcomes measure; $\mathrm{SF}=$ Short Form; $\mathrm{SE}=$ Standard Error; CI=Confidence Interval 
TABLE 2 Mood or Depression as Independent Variable, Posture as Dependent Variable. Smaller angles indicate worse kyphosis.

\begin{tabular}{|c|c|c|c|c|c|}
\hline $\begin{array}{l}\text { Source and } \\
\text { GRADE } \\
\text { Evidence Level }\end{array}$ & Purpose & $\begin{array}{l}\text { Design and } \\
\text { Sample }\end{array}$ & $\begin{array}{l}\text { Independent } \\
\text { Variable or } \\
\text { Intervention }\end{array}$ & $\begin{array}{l}\text { Dependent } \\
\text { Variable }\end{array}$ & Findings \\
\hline $\begin{array}{l}\text { Oosterwijk, } \\
\text { Rotteveel, } \\
\text { Fischer, Hess } 26 \\
\text { GRADE } \\
\text { Level: } \\
\text { Moderate }\end{array}$ & $\begin{array}{l}\text { To examine } \\
\text { whether the } \\
\text { activation of } \\
\text { emotions pride } \\
\text { and } \\
\text { disappointment } \\
\text { are accompanied } \\
\text { by changes in } \\
\text { posture. }\end{array}$ & $\begin{array}{l}\text { Double blind, } \\
\text { repeated } \\
\text { measures study } \\
57 \text { ( } 52 \text { women) } \\
\text { undergraduate } \\
\text { psychology } \\
\text { students, } \\
\text { primarily women }\end{array}$ & $\begin{array}{l}\text { Intervention: } \\
\text { Emotional } \\
\text { reactions (to } \\
\text { +/- emotional } \\
\text { photo) Control: } \\
\text { reaction to } \\
\text { non-emotional } \\
\text { photo (Wellbeing } \\
\text { Scale by Hess \& } \\
\text { Blairy) }\end{array}$ & $\begin{array}{l}\text { Posture (digital } \\
\text { camera software) }\end{array}$ & $\begin{array}{l}\text { Main effect for } \\
\text { concept (pride, } \\
\text { disappointment) } \\
\mathrm{F}(1,56)=5.07, \\
\mathrm{p}=.028 \\
\text { supporting with } \\
\text { disappointment, } \\
\text { posture height } \\
\text { decreased } \\
\text { significantly } \\
\text { more than } \\
\text { during the pride } \\
\text { task. Post-hoc } \\
\text { independent } \\
\text { t-test showed } \\
\text { increased } \\
\text { posture height } \\
\text { with positive } \\
\text { emotion } \\
\text { (t }(56)=.2 .76, \mathrm{p}<.004) \\
\text { Negative } \\
\text { emotion words } \\
\text { decreased } \\
\text { posture height } \\
\text { more than } \\
\text { positive emotion } \\
\text { words with } \\
\text { concept*time } \\
\text { interaction: } \\
\mathrm{F}(3,164)=2.82, \\
\mathrm{p}=.042 .\end{array}$ \\
\hline
\end{tabular}




\begin{tabular}{|c|c|c|c|c|c|}
\hline $\begin{array}{l}\text { Source and } \\
\text { GRADE } \\
\text { Evidence Level }\end{array}$ & Purpose & $\begin{array}{l}\text { Design and } \\
\text { Sample }\end{array}$ & $\begin{array}{l}\text { Independent } \\
\text { Variable or } \\
\text { Intervention }\end{array}$ & $\begin{array}{l}\text { Dependent } \\
\text { Variable }\end{array}$ & Findings \\
\hline $\begin{array}{l}\text { Canales, Cordas, } \\
\text { Fiquer, } \\
\text { Cavalcante, } \\
\text { Moreno } 28 \\
\text { GRADE } \\
\text { Level: } \\
\text { Moderate }\end{array}$ & $\begin{array}{l}\text { To quantify } \\
\text { posture and } \\
\text { body image in } \\
\text { patients with } \\
\text { major depressive } \\
\text { disorder (during } \\
\text { episodes and } \\
\text { after medication } \\
\text { treatment) } \\
\text { compared to } \\
\text { healthy } \\
\text { volunteers. }\end{array}$ & $\begin{array}{l}\text { 10-week, } \\
\text { non-randomized, } \\
\text { observational, } \\
\text { case-control } \\
\text { study } 34 \text { people } \\
\text { diagnosed with } \\
\text { major depression } \\
\text { disorder }(42.4+ \\
9.1 \text { years), }(77 \% \\
\text { female) } 37 \text { age } \\
\text { and gender ( } 78 \% \\
\text { female) matched } \\
\text { controls }\end{array}$ & $\begin{array}{l}\text { Treatment of } \\
\text { Depression (in } \\
\text { a mood disorders } \\
\text { clinic) }\end{array}$ & $\begin{array}{l}\text { Posture (digital } \\
\text { camera software) } \\
\text { Depression } \\
\text { (Hamilton } \\
\text { Rating Scale for } \\
\text { Depression) }\end{array}$ & $\begin{array}{l}\text { Kyphosis } \\
\text { significantly } \\
\text { worse in patients } \\
\text { with depression } \\
\text { compared to } \\
\text { controls at } \\
\text { baseline, (mean } \\
\sim 140 \pm 5^{\circ} \text { vs } \\
\left.\sim 145 \pm 6^{\circ}\right) \text {. With } \\
\text { treatment, those } \\
\text { with depression } \\
\text { showed improved } \\
\text { kyphosis by } 5^{\circ} \\
\text { and ressembled } \\
\text { controls } \\
(\mathrm{p}<0.001) .\end{array}$ \\
\hline $\begin{array}{l}\text { Aviezer, Trope, } \\
\text { Todorov } 29 \\
\text { GRADE } \\
\text { Level: } \\
\text { Moderate }\end{array}$ & $\begin{array}{l}\text { To examine } \\
\text { whether facial } \\
\text { expressions of } \\
\text { opposite } \\
\text { emotions would } \\
\text { overlap, and } \\
\text { whether the } \\
\text { body context } \\
\text { (posture) would } \\
\text { aid in } \\
\text { interpreting the } \\
\text { emotion. }\end{array}$ & $\begin{array}{l}\text { Comparative } 45 \\
\text { participants } \\
\text { rated emotional } \\
\text { reactions in } \\
\text { photos in various } \\
\text { settings - add } \\
\text { details Gender } \\
\text { not reported }\end{array}$ & $\begin{array}{l}\text { Intervention: } \\
\text { Emotional } \\
\text { reactions } \\
\text { (viewing photos } \\
\text { of face and } \\
\text { body) }\end{array}$ & $\begin{array}{l}\text { Posture (body } \\
\text { affective valence } \\
\text { by participant } \\
\text { rating on } 1-10 \\
\text { scale) }\end{array}$ & $\begin{array}{l}\text { Correct rating } \\
\text { when body } \\
\text { included } \\
\mathrm{F}(2,42)=74.05, \\
\mathrm{p}<.0001 \text {, but not } \\
\text { face alone p }>0.3 . \\
\text { Changed rating } \\
\text { of emotion based } \\
\text { on the } \\
\text { mismatched } \\
\text { body (not the } \\
\text { face) } \\
\mathrm{F}(1,14)=118, \\
\mathrm{p}<.0001 . \\
\text { Positive and } \\
\text { negative faces } \\
\text { rated incorrectly } \\
\mathrm{F}(1,14)=29.6, \\
\mathrm{p}<.0001, \text { but } \\
\text { when the body } \\
\text { was added, } \\
\text { emotions were } \\
\text { rated correctly } \\
\mathrm{F}(1,14)=96.9, \\
\mathrm{p}<.0001 .\end{array}$ \\
\hline
\end{tabular}




\begin{tabular}{|c|c|c|c|c|c|}
\hline $\begin{array}{l}\text { Source and } \\
\text { GRADE } \\
\text { Evidence Level }\end{array}$ & Purpose & $\begin{array}{l}\text { Design and } \\
\text { Sample }\end{array}$ & $\begin{array}{l}\text { Independent } \\
\text { Variable or } \\
\text { Intervention }\end{array}$ & $\begin{array}{l}\text { Dependent } \\
\text { Variable }\end{array}$ & Findings \\
\hline $\begin{array}{l}\text { Rosario, } \\
\text { Diógenes, } \\
\text { Mattei, Leite } \\
\text { GRADE } \\
\text { Level: Low }\end{array}$ & $\begin{array}{l}\text { To investigate } \\
\text { the existence of } \\
\text { a relationship } \\
\text { between sadness, } \\
\text { depression and } \\
\text { posture. }\end{array}$ & $\begin{array}{l}\text { Cross-sectional } \\
\text { descriptive study } \\
40 \text { volunteer } \\
\text { women ages } \\
20-30 \text { yo, normal } \\
\text { BMI an no } \\
\text { comorbidities }\end{array}$ & $\begin{array}{l}\text { Depression } \\
\text { (analogue scale } \\
0-10, \text { altered } \\
\text { Beck Depression } \\
\text { Inventory) }\end{array}$ & $\begin{array}{l}\text { Posture (digital } \\
\text { camera software) }\end{array}$ & $\begin{array}{l}\text { Depression and } \\
\text { sadness were } \\
\text { associated with } \\
\text { medium and } \\
\text { large effect sizes } \\
\text { of kyphotic } \\
\text { postures ( } \mathrm{r}= \\
.36-.51 ; \\
\mathrm{p}=.01-.05) . \\
\text { Strong } \\
\text { correlation } \\
\text { between "usual } \\
\text { depression" and } \\
\text { shoulder } \\
\text { inclination }(\mathrm{r}= \\
0.822 ; \mathrm{p}=0.02)\end{array}$ \\
\hline $\begin{array}{l}\text { Hepach, Vaish, } \\
\text { Tomasello } 30 \\
\text { GRADE } \\
\text { Level: } \\
\text { Moderate }\end{array}$ & $\begin{array}{l}\text { To measure } \\
\text { changes in } \\
\text { upper-body } \\
\text { posture related } \\
\text { to positive and } \\
\text { negative internal } \\
\text { states. }\end{array}$ & $\begin{array}{l}\text { Single blinded, } \\
\text { repeated } \\
\text { measures study } \\
12 \text { volunteer } \\
\text { students, ages } \\
14-37 \text { (median } \\
26 \text { years), } 50 \% \\
\text { female } 48 \\
\text { children, } 52 \% \\
\text { female, } 29-31 \\
\text { months old } \\
\text { (median } 30 \\
\text { months) }\end{array}$ & $\begin{array}{l}\text { Intervention: } \\
\text { Emotional } \\
\text { reactions } \\
\text { (adults: } \\
\text { imagining } \\
\text { positive or } \\
\text { negative; } \\
\text { children: } \\
\text { self-assessment- } \\
\text { manikin rating } \\
\text { scale) Rating } \\
\text { scale for how } \\
\text { pleasant an } \\
\text { emotion } \\
\text { experienced ( } 9= \\
\text { very pleasant, } \\
\text { 1= very } \\
\text { unpleasant) }\end{array}$ & $\begin{array}{l}\text { Posture (digital } \\
\text { camera software) }\end{array}$ & $\begin{array}{l}\text { Adults' had } \\
\text { more chest } \\
\text { height with } \\
\text { positive } \\
\text { emotions than } \\
\text { negative } \\
\text { (approx. } 2^{\circ}, \\
\mathrm{p}=0.012) \\
\text { Childrens' } \\
\text { emotions were } \\
\text { rated more } \\
\text { pleasant after } \\
\text { intervention }(\mathrm{M} \\
=6.45, \mathrm{SD}= \\
1.66) \text { compared } \\
\text { to the baseline } \\
(\mathrm{M}=5.83, \mathrm{SD}= \\
1.73) \text { trial, } t(41) \\
=2.24, \mathrm{p}=.031) \text {. } \\
\text { Children with } \\
\text { ratings of high } \\
\text { positive affect } \\
\text { showed greater } \\
\text { increase in } \\
\text { upper-body } \\
\text { posture (r= }=0.37 \text {; } \\
\mathrm{p}=.03) .\end{array}$ \\
\hline
\end{tabular}




\begin{tabular}{|c|c|c|c|c|c|}
\hline $\begin{array}{l}\text { Source and } \\
\text { GRADE } \\
\text { Evidence Level }\end{array}$ & Purpose & $\begin{array}{l}\text { Design and } \\
\text { Sample }\end{array}$ & $\begin{array}{l}\text { Independent } \\
\text { Variable or } \\
\text { Intervention }\end{array}$ & $\begin{array}{l}\text { Dependent } \\
\text { Variable }\end{array}$ & Findings \\
\hline $\begin{array}{l}\text { Canales, Fiquer, } \\
\text { Campos, } \\
\text { Soeiro-de-Souza, } \\
\text { Moreno } 27 \\
\text { GRADE } \\
\text { Level: } \\
\text { Moderate }\end{array}$ & $\begin{array}{l}\text { To investigate } \\
\text { associations } \\
\text { between poor } \\
\text { spinal posture } \\
\text { and recurrence of } \\
\text { major depressive } \\
\text { disorder. }\end{array}$ & $\begin{array}{l}\text { Prospective } \\
\text { comparative } \\
\text { cross-sectional } \\
\text { study } 72 \text { people } \\
\text { with depression, } \\
41 \text { with recurrent } \\
\text { depression ( } 58 \% \\
\text { female, age } 39 \\
\text { years, SD 9.5), } \\
31 \text { with single } \\
\text { episode } \\
\text { depression }(47 \% \\
\text { female, age } 37 \\
\text { years, SD 9.4) }\end{array}$ & $\begin{array}{l}\text { Depression } \\
\text { (Hamilton } \\
\text { Depression } \\
\text { Rating Scale) }\end{array}$ & $\begin{array}{l}\text { Posture (digital } \\
\text { camera software) }\end{array}$ & $\begin{array}{l}\text { Group with } \\
\text { recurrent } \\
\text { depression had } \\
\text { worse posture } \\
\text { than the group } \\
\text { with a single } \\
\text { episode (139.38, } \\
\text { SD 1.19, p < } \\
0.001) \text {. } \\
\text { Multivariate } \\
\text { analysis of } \\
\text { covariance } \\
\text { showed } \\
\text { interaction } \\
\text { between severity } \\
\text { of depression } \\
\text { and degree of } \\
\text { kyphosis (test } \\
\text { statistic not } \\
\text { reported, p = } \\
0.002 \text { ). }\end{array}$ \\
\hline
\end{tabular}

Legend: $\mathrm{M}=$ Mean; $\mathrm{SD}=$ Standard Deviation

TABLE 3 GRADE Rating Criteria Guidelines

Evidence Quality Definition

High $\quad$ Further research very unlikely to change confidence in the estimate of effect

Moderate $\quad$ Further research likely to have important impact on confidence in estimate of effect and may change the

Low Further research is very likely to have important impact on confidence in estimate of effect and is likely

Very Low We have very little confidence in the effect estimate.

FIGURE 1 Application of manual inclinometers for thoracic kyphosis measurement (photo used with written permission from author). ${ }^{39}$ 


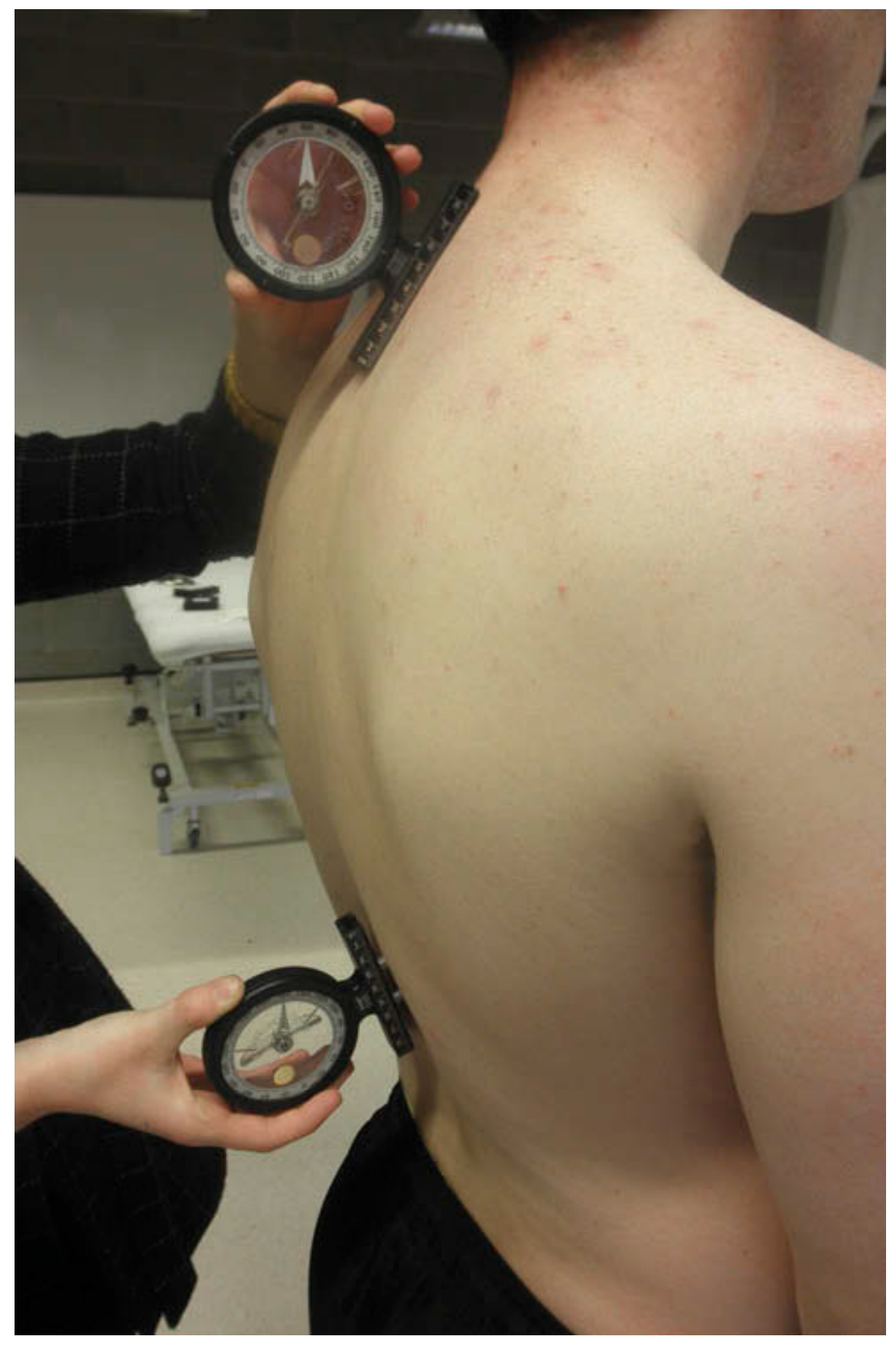

FIGURE 2 Preferred Reporting Items for Systematic Reviews and Meta-analyses (PRISMA) flow diagram of the systematic review article-screening procedure ${ }^{16}$ 


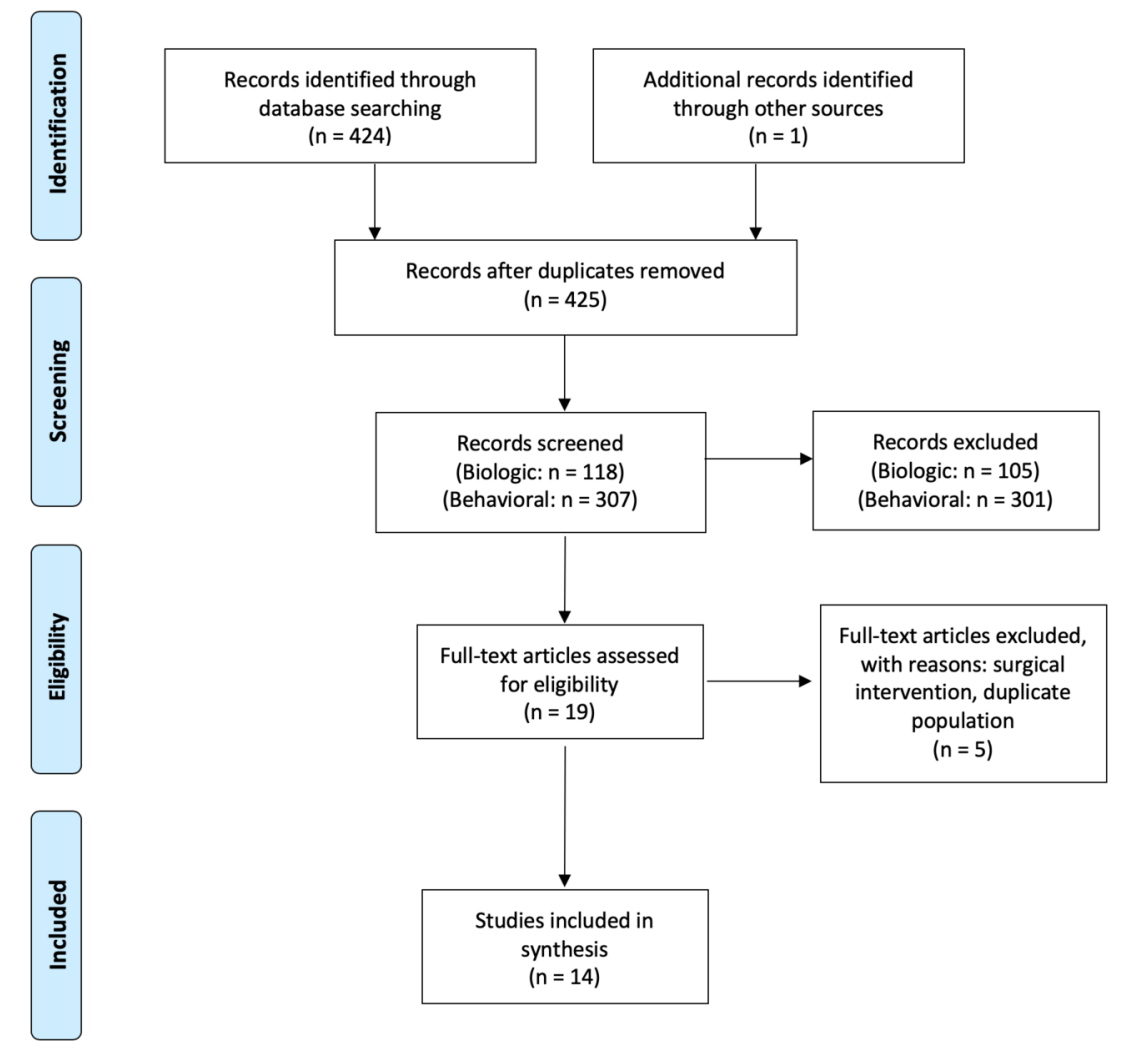

FIGURE 3 Conceptual Model of the Shape-Shifting Relationship between Posture and Quality of Life (QOL)

\section{Hosted file}

image3.emf available at https://authorea.com/users/427761/articles/545129-associationbetween-posture-and-quality-of-life-implications-for-children-with-cancer

References

1. Rosenberg AR, Wolfe J. Approaching the third decade of paediatric palliative oncology investigation: historical progress and future directions. Lancet Child Adolesc Health. 2017;1(1):56-67. 2. Derman YE, Deatrick JA. Promotion of Well-being During Treatment for Childhood Cancer: A Literature Review of Art Interventions as a Coping Strategy. Cancer Nurs. 2016;39(6):E1-E16. 3. Loeffen EA, Kremer LC, Mulder RL, et al. The importance of evidence-based supportive care practice guidelines in childhood cancer-a plea for their development and implementation. Support Care Cancer. 2017;25(4):1121-1125. 4. Varedi M, Lu L, Howell CR, et al. Peripheral neuropathy, sensory processing, and balance in survivors of acute lymphoblastic leukemia.J Clin Oncol. 2018;36(22):2315. 5. Varedi M, Lu L, Phillips NS, et al. Balance impairment in survivors of pediatric brain cancers: risk factors and associated physical limitations. J Cancer Surviv. 2021;15(2):311-324. 6. Einarsson E-J, Patel M, Petersen H, et al. Decreased postural control in adult survivors of childhood cancer treated with chemotherapy.Sci Rep. 2016;6(1):1-10. 7. Darwin C, Ekman P, Prodger P. The expression of the emotions in man and animals. Electronic Text Center, University of Virginia Library. 1872. 8. Noh DK, You JS, Koh JH, et al. Effects of novel corrective spinal technique on adolescent idiopathic scoliosis as assessed by radiographic imaging. J Back Musculoskelet Rehabil. 2014;27(3):331-338. 9. Hunter DJ, Rivett DA, McKiernan S, Weerasekara I, Snodgrass SJ. Is the inclinometer a valid measure of thoracic kyphosis? A cross-sectional study. Braz J Phys Ther. 2018. 10. Campbell ML, Donesky D, Sarkozy A, Reinke LF. Treatment of Dyspnea in Advanced Disease and at the End of Life. 
J Hosp Palliat Nurs.2021;23(5):406-420. 11. Campbell ML. Assessing respiratory distress when the patient cannot report dyspnea. Nurs Clin North Am. 2010;45(3):363-373. 12. Raybin JL, Hendricks-Ferguson V, Cook P, Jankowski C. Associations between demographics and quality of life in children in the first year of cancer treatment. Pediatr Blood Cancer. 2021:e29388. 13. Raybin JL, Jankowski CM. Quality of Life Outcomes with Creative Arts Therapy in Children with Cancer. J Pediatr Oncol Nurs. in press. 14. Califf RM. Biomarker definitions and their applications. Exp Biol Med (Maywood). 2018;243(3):213-221. 15. Corwin EJ, Meek P, Cook PF, Lowe NK, Sousa KH. Shape shifters: biobehavioral determinants and phenomena in symptom research. Nurs Outlook. 2012;60(4):191-197. 16. Moher D, Liberati A, Tetzlaff J, Altman DG. Preferred reporting items for systematic reviews and meta-analyses: the PRISMA statement.Ann Intern Med. 2009;151(4):264-269. 17. Andrews J, Guyatt G, Oxman AD, et al. GRADE guidelines: 14. Going from evidence to recommendations: the significance and presentation of recommendations. J Clin Epidemiol. 2013;66(7):719-725. 18. Balshem H, Helfand M, Schünemann HJ, et al. GRADE guidelines: 3. Rating the quality of evidence. J Clin Epidemiol.2011;64(4):401-406. 19. Dias N, Hendricks-Ferguson VL, Wei H, Boring E, Sewell K, Haase JE. A Systematic Literature Review of the Current State of Knowledge Related to Interventions for Bereaved Parents. Am J Hosp Palliat Care.2019;36(12):1124-1133. 20. Rodgers CC, Laing CM, Herring RA, et al. Understanding Effective Delivery of Patient and Family Education in Pediatric OncologyA Systematic Review From the Children's Oncology Group [Formula: see text]. J Pediatr Oncol Nurs. 2016;33(6):432-446. 21. Petcharaporn M, Pawelek J, Bastrom T, Lonner B, Newton PO. The relationship between thoracic hyperkyphosis and the Scoliosis Research Society outcomes instrument. Spine (Phila Pa 1976).2007;32(20):2226-2231. 22. Sangtarash F, Manshadi F, Sadeghi A. The relationship of thoracic kyphosis to gait performance and quality of life in women with osteoporosis. Osteoporos Int. 2015;26(8):2203-2208. 23. Rosario JL, Diógenes MSB, Mattei R, Leite JR. Differences and similarities in postural alterations caused by sadness and depression.J Bodyw Mov Ther. 2014;18(4):540-544. 24. Lonner B, Yoo A, Terran JS, et al. Effect of spinal deformity on adolescent quality of life: comparison of operative scheuermann kyphosis, adolescent idiopathic scoliosis, and normal controls.Spine (Phila Pa 1976). 2013;38(12):1049-1055. 25. Miyakoshi N, Kudo D, Hongo M, Kasukawa Y, Ishikawa Y, Shimada Y. Comparison of spinal alignment, muscular strength, and quality of life between women with postmenopausal osteoporosis and healthy volunteers. Osteoporos Int. 2017;28(11):3153-3160. 26. Oosterwijk S, Rotteveel M, Fischer AH, Hess U. Embodied emotion concepts: How generating words about pride and disappointment influences posture. Eur $J$ Soc Psychol. 2009;39(3):457-466. 27. Canales JZ, Fiquer JT, Campos RN, Soeiro-de-Souza MG, Moreno RA. Investigation of associations between recurrence of major depressive disorder and spinal posture alignment: A quantitative cross-sectional study. Gait Posture. 2017;52:258-264. 28. Canales JZ, Cordas TA, Fiquer JT, Cavalcante AF, Moreno RA. Posture and body image in individuals with major depressive disorder: a controlled study. Rev Bras Psiquiatr. 2010;32(4):375-380. 29. Aviezer H, Trope Y, Todorov A. Body cues, not facial expressions, discriminate between intense positive and negative emotions.Science. 2012;338(6111):1225-1229. 30. Hepach R, Vaish A, Tomasello M. Novel paradigms to measure variability of behavior in early childhood: posture, gaze, and pupil dilation. Front Psychol. 2015;6:858. 31. Greendale GA, Huang MH, Karlamangla AS, Seeger L, Crawford S. Yoga decreases kyphosis in senior women and men with adult-onset hyperkyphosis: results of a randomized controlled trial. J Am Geriatr Soc. 2009;57(9):1569-1579. 32. Jang H-J, Hughes LC, Oh D-W, Kim S-Y. Effects of Corrective Exercise for Thoracic Hyperkyphosis on Posture, Balance, and Well-Being in Older Women: A Double-Blind, Group-Matched Design. Journal of geriatric physical therapy (2001). 2017. 33. Katzman WB, Parimi N, Gladin A, et al. Sex differences in response to targeted kyphosis specific exercise and posture training in community-dwelling older adults: a randomized controlled trial.BMC Musculoskelet Disord. 2017;18(1):509. 34. Walicka-Cuprys K, Wyszynska J, Podgorska-Bednarz J, Drzal-Grabiec J. Concurrent validity of photogrammetric and inclinometric techniques based on assessment of anteroposterior spinal curvatures. Eur Spine J. 2018;27(2):497-507. 35. Schindel CS, Hommerding PX, Melo DA, Baptista RR, Marostica PJ, Donadio MV. Physical exercise recommendations improve postural changes found in children and adolescents with cystic fibrosis: a randomized controlled trial. J Pediatr. 2015;166(3):710-716 e712. 36. Linder L. Analysis of the UCSF Symptom Management Theory: implications for pediatric oncology nursing. J Pediatr Oncol Nurs. 2010;27(6):316-324. 37. Joshi SH, Espinoza RT, Pirnia T, et al. Structural Plasticity of the Hippocampus and Amygdala Induced by Electroconvulsive 
Therapy in Major Depression. Biol Psychiatry. 2016;79(4):282-292. 38. Michielsen M, Vaughan-Graham J, Holland A, Magri A, Suzuki M. The Bobath concept - a model to illustrate clinical practice. Disabil Rehabil. 2019;41(17):2080-2092. 39. Barrett E, Lenehan B, O'Sullivan K, Lewis J, McCreesh K. Validation of the manual inclinometer and flexicurve for the measurement of thoracic kyphosis. Physiother Theory Pract. 2018;34(4):301-308. 